\title{
Systematics and bird conservation policies: the importance of species limits
}

\author{
OCTAVIO R. ROJAS-SOTO, ADOLFO G. NAVARRO-SIGÜENZA and \\ ALEJANDRO ESPINOSA DE LOS MONTEROS
}

\begin{abstract}
Summary
The taxonomic criteria used as bases for endangered species lists can affect conservation policy decisions. We emphasize that the use of different taxonomic units affects the baselines of such lists. Recent taxonomic reviews for the Mexican avifauna provided the tools for assessing this effect on a highly diverse avifauna which is currently in need of serious conservation actions. Most ornithologists have used a taxonomy based on the biological species concept (BSC) to make decisions on species limits and therefore to set them into endangered species lists. However, the application of the phylogenetic species concept (PSC) as an alternative for delimiting species, results in a different panorama of what should be protected. Our analysis shows that the current official Mexican endangered species list, BSC based, encompasses 371 birds, ranked as 277 species and 94 subspecies. The same list of protected forms changes under the phylogenetic species concept because 47 of them are not recognized as valid species, while another 28 forms merit higher levels of protection. Additionally, under this concept another 11 forms should be candidates for inclusion based on their restricted distribution. We call attention to the fact that the use of one or another species concept affects endangered species lists.
\end{abstract}

\section{Resumen}

Los criterios taxonómicos usados como base para la creación de listas de especies en riesgo, pueden afectar las decisiones en las políticas de conservación. Enfatizamos que el uso de diferentes unidades taxonómicas afecta las bases para estas listas. Recientes revisiones taxonómicas para la avifauna mexicana proveen las herramientas para determinar este efecto en una avifauna altamente diversa, la cual posee la necesidad de acciones serias de conservación. La mayoría de los ornitólogos han usado una taxonomía basada en el concepto biológico de especie (CBE) para tomar decisiones sobre los límites entre las especies y por lo tanto incluirlas en las listas de especies en riesgo. Sin embargo, la aplicación del concepto filogenético de especie (CFE) como una alternativa para la delimitación de especies, genera un panorama diferente de lo que debería ser protegido. Nuestro análisis muestra que la actual lista oficial Mexicana de especies bajo riesgo, basada en el CBE, abarca 371 aves, categorizadas en 277 especies y 94 subespecies. La misma lista de formas protegidas cambia bajo el concepto filogenético de especie, por que 47 de ellas no son reconocidas como especies válidas, mientras que otras 28 formas merecen mayores niveles de protección. Adicionalmente, bajo este concepto otras 11 formas podrían ser candidatas para su inclusión con base en su distribución restringida. Recalcamos que el hecho de usar un concepto u otro afecta las listas de especies en riesgo.

\section{Introduction}

Identification of natural groups and assigning appropriate taxonomic ranks are among the main goals in systematics, and have become a key issue in conservation biology (Kelt and Brown 2000, Fraser and Bernatchez 2001). Different viewpoints on species limits lead to different priorities for 
conservation assessments; hence, species concepts are of great importance in conservation (Hazevoet 1996, Peterson and Navarro 1999, Peterson 2006), particularly when they extend to public and governmental agendas in which biodiversity protection is legislated. However, generating endangered species lists relies on a range of taxonomic surveys that sometimes lack a general agreement among scientists, thus making it difficult to assess conservation tags (i.e. units or areas) among regions and countries, especially if definitions of a species vary from place to place and from taxon to taxon (Goldstein et al. 200o). Also, the taxonomic validity of subspecies has been debated for more than 40 years, a debate that can affect conservation decisions (Ryder 1986, Ball and Avise 1992, Wilcove et al. 1993, Barrowclough and Flesness 1996, Cracraft 1997, Zink 2004). Despite different points of view on the validity of subspecies, they have been considered as conservation units by several international conventions and organizations such as CITES (Inskipp and Gillett 2005) and IUCN (IUCN 2009), as well as in official endangered species lists of countries such as Brazil (MMA 2003), Australia (EPBCA 1999), Mexico (DOF 2002), United States (ESA 1973), Canada (SRA 2003), and Spain (Catálogo Nacional de Especies Amenazadas 2002). Hence, it is desirable to try to arrive at consistent nomenclatural units on which to establish conservation strategies.

Mexico holds approximately 1,06o biological species of birds, $\sim 28 \%$ of which are listed under some national risk status. The NOM-059-ECOL-2001 (DOF 2002; hereafter "NOM") is the official list of threatened and endangered taxa protected by Mexican legislation, and is also the framework for conservation policies, commercial ventures involving biodiversity, environmental impact studies, hunting regulations, ecotourism development, and scientific collecting permits. Taxa are listed in the NOM based on several attributes: population size, distributional area, human impacts, and population trends. Taxa are placed in one of four NOM risk categories: extinct, endangered, threatened, or subject to special protection, the latter referring to taxa with insufficient information regarding their risk of extinction. Taxa included in the NOM can be either species or subspecies. These taxonomic units are based on the currently recognized taxonomic authority for each taxon. For birds, the authority list is that of Friedmann et al. (1950), Miller et al. (1957) and AOU (1998; and recent addenda, http://www.aou.org), all based on the traditional Biological Species Concept (BSC; Mayr 1942).

An alternative species-level taxonomy was recently proposed for Mexican bird species by Navarro-Sigüenza and Peterson (2004; hereafter N\&P), who outlined a taxonomy under the Phylogenetic Species Concept (PSC) and Evolutionary Species Concept (ESC) (Navarro-Sigüenza and Peterson 2004). Their taxonomy was based largely on evidence from morphology, genetic data, and vocalizations when available (see literature cited by N\&P). Thus 135 biological species became 323 species, 122 of which represent "new" endemic forms for Mexico, and another 29 forms suggested as additional candidates for splitting. Although such a rise in the number of species may seem huge, it falls within the expected rate of 1.9 phylogenetic species per biological species detected by Zink (2004). This list of phylogenetic species, contrasted with biological species, provides the basis for the results reported here.

Because the diverse concepts for conservation units have been analyzed in detail in the literature (Riddle and Hafner 1999, Kelt and Brown 2000, Fraser and Bernatchez 2001), our goal focuses on analyzing whether species and taxa defined by $\mathrm{N} \& \mathrm{P}$ would provide a different approach for constructing endangered species lists and different prioritisation schemes, in contrast with schemes based on BSC and subspecies by using the Mexican avifauna as an example.

\section{Methods}

We compared the list of species and subspecies listed on the NOM with that of N\&P (Fig. I, Appendix 1 in Supplementary materials). Protected species usually contained multiple subspecies under different risk categories, so each component form was evaluated independently of its taxonomic category (e.g., Least Tern Sternula antillarum is subject to special protection, but $S$. $a$. browni is catalogued as endangered). 
We identified four management categories that encompass the analysis of putative taxa under risk: (1) Concordant protected forms: BSC species and subspecies listed in the NOM that correspond to phylogenetic species recognized by N\&P. (2) Discordant protected forms: BSC species and subspecies that do not correspond to a phylogenetic species as recognized by $\mathrm{N} \& \mathrm{P}$, and that may not represent biological entities meriting protection. (3) Underprotected forms: species recognized by $\mathrm{N} \& \mathrm{P}$ that do not correspond directly to any current protected taxon but that are part of a protected BSC species listed in the NOM, at a lower risk category than presumably is merited under a PSC view point (e.g., Oaxaca Screech-owl Megascops lambi, subject to special protection as part of Pacific Screech-owl M. cooperi). (4) Unprotected forms: species recognized by N\&P that have restricted geographic distributions but are not listed in the NOM because they are not currently recognized as biological species (Fig. $1 \mathrm{~b}$ ).

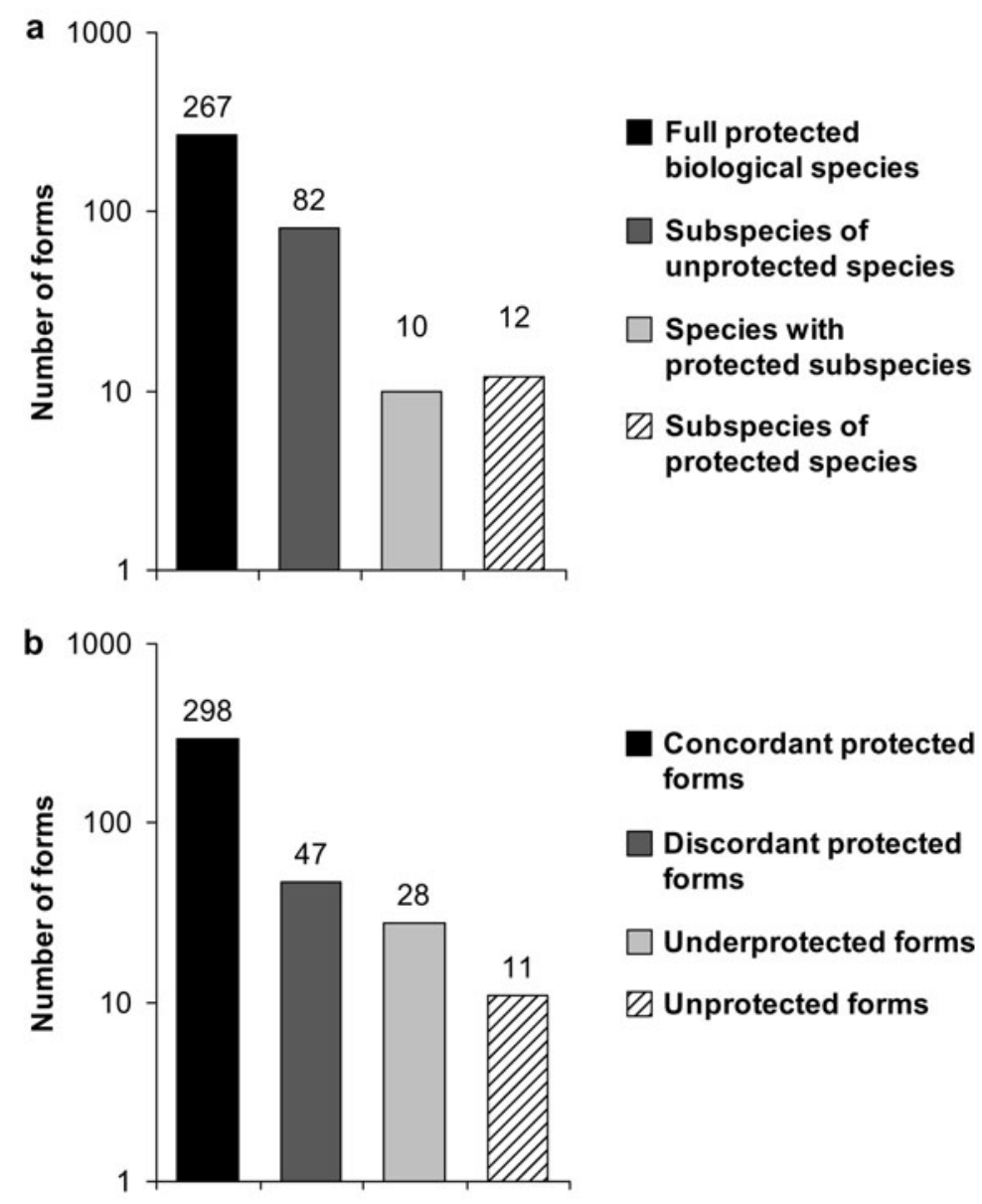

Figure 1. Number of current NOM protected avian species and subspecies (a), and changes in the NOM removing the subspecific category and considering the use of phylogenetic species proposed by Navarro and Peterson (2004) (b). In (b), the number of forms (373 considering only the concordant, the underprotected and the unprotected forms) does not coincide with those protected by the NOM (371) due to the existence of two indirectly protected forms but unrecognized by the NOM (see Appendix $I$ in Supplementary materials). Y axes are logtransformed for better visualization. 
Finally, we used a chi-square analysis to analyze the differences among the risk categories (endangered, threatened and special protection) by species concept (Fig. 2) considering two datasets: a) the total number of protected forms (by risk category) per species concept, and b) the number of forms (by risk category) exclusively protected by each species list.

\section{Results}

Of the 371 bird taxa listed in the NOM (Appendix 1 in Supplementary materials), 277 correspond to species and 94 to subspecies (note that 12 of these protected subspecies are included within 10 of the 277 protected species; however, as stated in methods, those were counted independently; Fig. 1a). In N\&P, these numbers correspond to 298 species, of which 269 are concordant protected species and 29 are concordant protected subspecies (e.g., Jabiru Jabiru mycteria or San Lucas Robin Turdus migratorius confinis, forms recognized by both NOM and N\&P, Fig. $1 \mathrm{~b}$ ).

We identified 47 discordant protected forms, most of them Baja California subspecies of widespread taxa (e.g., a local form of Great Blue Heron Ardea herodias sanctilucae, Appendix 1 in Supplementary materials). Two of these forms are included within a protected full biological species with distinct risk category: Northern Aplomado Falcon Falco femoralis septentrionalis and a form of Great Curassow Crax rubra griscomi.

The 28 under-protected phylogenetic species (Appendix 1 in Supplementary materials) include an interesting set of forms that exist in isolation in mountain ranges or islands, like White-breasted Hawk Accipiter (striatus) chionogaster, Salle's Quail Cyrtonyx (montezumae) sallei, forms of Band-tailed Pigeon Patagioenas (fasciata) vioscae, Yellow-headed Amazon Amazona (oratrix) tresmariae and Turdus (migratorius) confinis, among others.

Considering their restricted distributions, II phylogenetic species (Unprotected forms; Fig. Ib, Table I) are considered good candidates for official protection, although not accorded any protected status previously. Such forms include phylogenetic species like Roadside Hawk Buteo gracilis or Vizcaino Thrasher Toxostoma arenicola, two examples that will be discussed below.

Based on the two species lists (BSC and PSC), the variation among numbers of total forms changed respectively from 72 to 67 for "endangered"; from 107 to 110 for "threatened", and

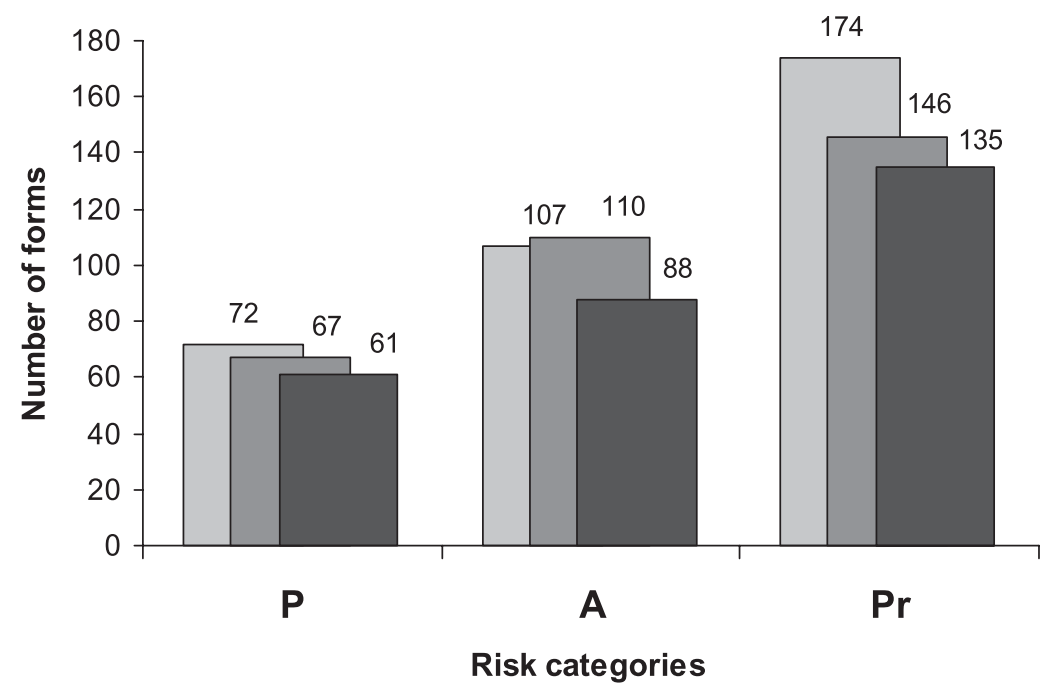

Figure 2. Number of forms protected under the three risk categories $(\mathrm{P}=$ endangered, $\mathrm{A}=$ threatened, and $\mathrm{Pr}=$ special protection) considering the biological species concept (light grey) and the phylogenetic species concept (dark grey). Black indicates the forms protected by both concepts. 
Table 1 . List of unprotected phylogenetic species which are not included in the NOM.

\begin{tabular}{|c|c|c|}
\hline Phylogenetic species & Distribution & Biological species/subspecies \\
\hline Buteo gracilis & Cozumel and Holbox islands & B. magnirostris/gracilis \\
\hline Otus vinaceus & $\begin{array}{l}\text { S Sonora and } \mathrm{W} \text { Chihuahua } \\
\text { to N Sinaloa }\end{array}$ & $\begin{array}{l}\text { O. kennicottii/vinaceus, } \\
\text { sinaloensis }\end{array}$ \\
\hline Glaucidium cobanense & Chiapas to Honduras & G. gnoma/cobanense \\
\hline Cyanocitta ridgwayi & Chiapas to Nicaragua & C. stelleri/ridgwayi \\
\hline Campylorhynchus nelsoni & SW Veracruz $S$ to $C$ Oaxaca & C. megalopterus/nelsoni \\
\hline Toxostoma arenicola & $\begin{array}{l}\text { Vizcaino Desert in central } \\
\text { Baja California }\end{array}$ & T. lecontei/arenicola \\
\hline Geothlypis chapalensis & Lake Chapala, Jalisco & G. trichas/chapalensis \\
\hline Amaurospiza relicta & Guerrero, Morelos and Oaxaca & A. concolor/relicta \\
\hline Pipilo nigrescens & Jalisco and Michoacán & P. ocai/nigrescens \\
\hline Pipilo albigula & Cape Region, Baja California Sur & P. crissalis/albigula \\
\hline Junco fulvescens & N Chiapas highlands & J. phaeonotus/fulvescens \\
\hline
\end{tabular}

from 174 to 146 for "special protection" (Fig. 2 ) which do not differ statistically $\left(\chi_{2}^{2}=1.34, P=\right.$ 0.511 ). However, considering the number of forms exclusively protected by each of the species lists, the differences vary from II to 6 for "endangered", 19 to 22 for "threatened", and 39 toII for "special protection" (Fig. 2), differences that are statistically distinct $\left(\chi_{2}^{2}=9.79, P=0.007\right)$.

\section{Discussion}

Lack of correspondence between taxonomic lists based on different species concepts may generate inconsistencies in the identification of taxa that merit protection according any particular legislation. Our results suggest that the current number of forms listed by the NOM (371; Fig. Ia) decreases to 337 species considering the PSC (Fig. Ib). This reduction follows the exclusion of discordant forms (i.e. poorly differentiated subspecies) even considering the inclusion of unprotected taxa. However, an increase in the list from 277 BSC forms (Fig. 1a) to 337 PSC taxa (Fig. Ib) occurs only if the species category is considered. Modifications of this magnitude based on the application of alternative species taxonomy would make a significant difference, not only for conservation strategies and priorities for the Mexican avifauna (Peterson and Navarro 1999), but also worldwide (Dillon and Fjeldså 2005).

The discordant protected forms identified include 47 subspecies that represent minor variants of broadly distributed species, therefore not considered by $\mathrm{N} \& \mathrm{P}$ as species. As an example, the California Gnatcatcher Polioptila californica has been subdivided differently in three treatments (Miller et al. 1957, Atwood 1991, Mellink and Rea 1994), rendering ambiguous infraspecific patterns of variation. P. c. atwoodi (ranging from west of the Sierra San Pedro Mártir to the USMexican border, Mellink and Rea 1994) is listed as "threatened". However, Zink et al. (2000) found no genetic differentiation among these populations that might justify division below the species level. Indeed, even the validity of $P$. c. californica, the subspecies used as a flagship for habitat conservation in California, has been questioned: Zink et al. (2000) suggested a single, recently expanded population across the species's range.

Discordant protected forms also include widely distributed species containing well-differentiated sub-populations that deserve higher levels of protection. For example, the widespread Kentucky Warbler Oporornis tolmiei is categorized as threatened as a whole, based on an isolated breeding population that is differentiated genetically and morphologically from other populations of the species. This population remains taxonomically undescribed (Milá et al. 2000) and may best be added to the list of underprotected forms, based on its very restricted distribution in northeastern Mexico. Other such examples of discordant protection are listed in Appendix 1 in Supplementary materials. 
Evidence of the existence of taxa that are underprotected or underappreciated throughout the world is becoming available more often as research in song, behaviour, and phylogeography develops. Examples of allopatric populations with long-term evolutionary independence, especially among montane and insular taxa that have coupled genetic and morphological differentiation associated with geographic breaks (e.g., Milá et al. 2000, García-Moreno et al. 2004, 2006).

The vast majority of the underprotected forms detected by us result from lack of recognition of allopatric populations as separate species. For example, Yellow-headed Amazon Amazona oratrix is listed as endangered, but the form endemic to the Tres Marías Islands (A. tresmariae, sensu $\mathrm{N} \& \mathrm{P})$ is listed only as threatened, even though it has a more restricted distribution and its population has been estimated as less than 800 birds (Howell 2004). Eberhard and Bermingham (2004) came to the conclusion, based on molecular and plumage character analysis, that all Mesoamerican forms (including A. o. tresmariae and A. o. oratrix) should be considered as distinct units for conservation purposes. Therefore, threat status should be higher due to restricted distribution and small population size.

Another example involves the allopatric populations of the highly polytypic Emerald Toucanet Aulacorhynchus prasinus complex, presently listed as subject to special protection in Mexico. Although up to six subspecies have been described in Mexico (A. p. prasinus, A. p. virescens. A. $p$. wagleri. A. p. stenorhabdus, A. p. chiapensis and A. p. warneri; Miller et al. 1957, Winker 2000), morphology (Navarro et al. 2001), and molecular characters (Puebla-Olivares et al. 2008) converge on the conclusion that the Sierra Madre del Sur (Guerrero and western Oaxaca) A. $p$. wagleri should be accorded species status and ranked in a higher conservation category given its restricted range and low abundance. The application of BSC criteria may result in the restricted geographic distribution, narrow ecological range and small population size of such forms being overlooked, thus limiting also the assignation of conservation status.

Approximately 11 micro-endemic forms were identified by N\&P that have been overlooked in any protection category (Fig. Ib, Table I). For example, the form of Roadside Hawk Buteo [magnirostris] gracilis, endemic to Cozumel Island, is one of the most endangered Mexican bird taxa (Howell 2004), yet has been ignored by the current legislation. Similarly, the Vizcaino Thrasher Toxostoma [lecontei] arenicola is well-differentiated in mtDNA characters and coloration (Zink et al. 1997), suggesting that the taxon is a different species, and the only bird endemic to the Vizcaino Desert of central Baja California. Another nine potentially endangered species (Table I) were selected based only on restricted geographic distributions, so consideration of more and broader information it is necessary to corroborate their risk status.

In general, our analysis suggests that once a species is split or aggregated, its position in any of the priority listings of threatened and endangered species should be carefully reassessed, given that such changes could transform a biological species into a set of phylogenetic species, some of which may prove to be of very restricted distribution, inhabit isolated and endangered habitats, and/or have small population sizes.

Considering the protection scenarios based on the two species concepts, the amount of change in the number of total protected forms by risk category statistically remains the same (Fig. 2). However, considering the number of forms by risk category that are protected exclusively by each species concept, then the differences vary statistically. Thus, the major difference between lists is based on which forms are exclusively protected by each list. Differences between the two scenarios result mainly from the use of subspecies under BSC, leading to the incorporation of 75 forms at different levels (discordant and underprotected forms, Fig. $1 \mathrm{~b}$ ), representing almost $20 \%$ of the total BSC list.

As more studies find a lack of correspondence between subspecies boundaries and historical groups obtained by phylogenetic analyses, taxonomic recommendations resulted in that many subspecies are either synonymised, or given full species status, particularly in species showing continuous distributions and clinal variation and based in morphology, molecular, and vocal data sets (e.g. Barrowclough and Gutierrez 1990, Zink 1994, Marín 1997, Burns 1998, Pitman and Jehl 1998, Friesen et al. 2002, Leger and Mountjoy 2003, García-Moreno et al. 2004, Zink et al. 2005, 
Rising 2007). Within this framework, governments compose endangered taxa lists based on the expertise of the scientific community. Scientists using diverse taxonomic criteria for recognition of forms that should be encompassed in the catalogues should devote their efforts to the goal of conserving biodiversity by compiling, advising, and commenting on such lists. However, the general resurvey of the world's avifauna under alternative species concepts in wide regions has only begun (see Christidis and Boles 2008 for Australia), and more taxa remain unstudied than those that have been subject of analysis, creating a notably unbalanced alpha taxonomy for the global avifauna (Navarro-Sigüenza and Peterson 2004, Peterson 2006). This problem has influenced conservation due to the use of subspecies that in diverse cases might not represent evolutionary units and processes at any scale, and the flaw of not detecting several significant conservation units.

Given that conservation priorities depend critically on the particular authority employed, and that mixed-species-concept prioritizations may yield unpredictable results as has been demonstrated for the endemic avifauna in Mexico (Peterson and Navarro 1999) and the Philippines (Peterson 2006), we suggest that progress in delimitation of conservation units will be greatly improved by the advance in species concept debate, instead of being impeded by it (Winker et al. 2007). We need agreement on the taxonomic basis for taxa to make risk categories comparable within and among countries, which would contribute to improvement in policies for bird conservation.

\section{Acknowledgments}

A. T. Peterson, R. M. Zink, N. Mercado-Silva, and J. F. Ornelas provided important comments on the manuscript. The staff of the Museo de Zoología, F. C., UNAM and Instituto de Ecología, A. C., encouraged the generation of this manuscript through discussions of subspecies concepts and conservation. Funding was obtained from SEMARNAT-CONACYT Sectorial Fund (Co1-0265).

\section{References}

AOU (1998) Check-list of North American birds, 7 th ed. Washington DC: American Ornithologists' Union.

Atwood, J. L. (1991) Subspecies limits and geographic patterns of morphological variation in California Gnatcatchers (Polioptila californica). Bull. Southern Calif. Acad. Sci. 90: 118-133.

Ball, R. M. and Avise, J. C. (1992) Mitochondrial DNA phylogeographic differentiation among avian populations and the evolutionary significance of subspecies. Auk 109: 626-636.

Barrowclough, G. F. and Flesness, N. R. (1996) Species, subspecies, and races: the problem of units of management in conservation. Pp. 247-254 in G. G. Kleiman, M. Allen, and H. Harris, eds. Wild mammals in captivity. Chicago: University of Chicago Press.
Barrowclough, G. F. and Gutierrez, R. J. (1990) Genetic variation and differentiation in the Spotted Owl (Strix occidentalis). Auk 107: 737-744.

Burns, K. J. (1998) Molecular phylogenetics of the genus Piranga: implications for biogeography and the evolution of morphology and behavior. Auk 115: 621-634.

Catálogo Nacional de Especies Amenazadas (2002) Boletín Oficial del Estado, Orden $M A M / 2734 / 2002$. Madrid: Ministerio del Medio Ambiente.

Christidis, L. and Boles, W. E. (2008) Systematics and taxonomy of Australian birds. Collingwood, Australia: CSIRO Publishing.

Cracraft, J. (1997) Species concepts in systematics and conservation biology: an ornithological viewpoint. Pp. 325-339 in M. F. Claridge, H. A. Dawah, and M. R. Wilson, 
eds. Species: The units of biodiversity. London: Chapman and Hall.

Dillon, S. and Fjeldså, J. (2005) The implications of different species concepts for describing biodiversity patterns and assessing conservation needs for African birds. Ecography 28: 1-11.

DOF (Diario Oficila de la Federación) (2002) Norma Oficial Mexicana NOM-059ECOL-2001 Protección ambiental, especies nativas de México de flora y fauna silvestres, categorias de riesgo y especificaciones para su inclusión, exclusión o cambio-Lista de especies en riesgo. Mexico D.F: Secretaría de Medio Ambiente y Recursos Naturales, Diario Oficial de la Federación.

Eberhard, J. R. and Bermingham, E. (2004) Phylogeny and biogeography of the Amazona ochrocephala (Aves: Psittacidae) complex. Auk 121: 318-332.

ESA (Endangered Species Act) (1973) Washington DC: U.S. Fish and Wildlife Service, Available from http://www.fws.gov/ endangered/esa.html (accessed July 2006).

EPBCA (Environment Protection and Biodiversity Conservation Act) (1999) AttorneyGeneral's Department. National Circuit Barton Act 26oo. Available from http:// www.comlaw.gov.au/comlaw/management. nsf/lookupindexpagesbyid/IP200401830 (accessed May 2007).

Fraser, D. J. and Bernatchez, L. (2001) Adaptive evolutionary conservation: towards a unified concept for defining conservations units. Mol. Ecol. 10: 2741-2752.

Friedmann, H., Griscom, L. and Moore, R. T. (1950) Distributional check-list of the birds of Mexico. Part I. Pac. Coast Avif. 29: 1-202.

Friesen, V. L., Anderson, D. J., Steeves, T. E., Jones, H. and Schreiber, E. A. (2002) Molecular support for species status of the Nazca Booby (Sula granti). Auk 119: $820-826$.

García-Moreno, J., Navarro-Sigüenza, A. G., Peterson, A. T. and Sánchez-González, L. A. (2004) Genetic variation coincides with geographic structure in the common bush tanager (Chlorospingus ophthalmicus) complex from Mexico. Mol. Phylogenet. Evol. 33: 186-196.
García-Moreno, J., Cortés, N., García-Deras, G. M. and Hernández-Baños, B. E. (2006) Local origin and diversification among Lampornis hummingbirds: A Mesoamerican taxon. Mol. Phylogenet. Evol. 38: 488498.

Goldstein, P. Z., DeSalle, R., Amato, G. and Vogler, A. P. (2000) Conservation genetics at the species boundary. Conserv. Biol. 14: 120-131.

Hazevoet, C. J. (1996) Conservation and species lists: taxonomic neglect promotes the extinction of endemic birds, as exemplified by taxa from eastern Atlantic islands. Bird Conserv. Internatn. 6: 181196.

Howell, S. N. G. (2004) An update on status of birds from Isla Cozumel, Mexico. Cotinga 22: 15-19.

Inskipp, T. and Gillett, H. J. (2005) Checklist of CITES species and annotated CITES appendices and reservations. Geneva: CITES Secretariat.

IUCN 2009. IUCN Red List of threatened species. Version 2009.2. www.iucnredlist. org Downloaded on 26 March 2009.

Kelt, D. A. and Brown, J. H. (2000) Species as units of analysis in ecology and biogeography: are the blind leading the blind? Glob. Ecol. Biogeogr. 9: 213-217.

Leger, D. W. and Mountjoy, D. J. (2003) Geographic variation in song of the Bright-rumped Attila (Tyrannidae: Attila spadiceus): implications for species status. Auk 120: 69-74.

Marín, M. (1997) Species limits and distribution of some New World spine-tailed swifts (Chaetura spp.). Ornithol. Monogr. 48: 399-42.

Mayr, E. (1942) Systematics and the origin of species. New York: Columbia University Press.

Mellink, E. and Rea, A. M. (1994) Taxonomic status of the California gnatcatchers of northwestern Baja California. Western Birds 25: 50-62.

Milá, B., Girman, D. J., Kimura, M. and Smith, T. B. (2000) Genetic evidence for the effect of a postglacial population expansion on the phylogeography of a North American songbird. Proc. Royal Soc. London. B 267: 1033-1040. 
Miller, A. H., Friedmann, H., Griscom, L. and Moore, R. T. (1957) Distributional check list of the birds of Mexico (Part II). Berkeley, California: Cooper Ornithological Club.

MMA (Ministério do Meio Ambiente) (2003) Lista Nacional das Espécies da Fauna Brasileira Ameaçadas de Extinção. Brasília. Available from http://www.mma.gov.br (accessed May 2006).

Navarro, A. G., Peterson, A. T., LópezMedrano, E. and Benítez-Díaz, H. (2001) Species limits in Mesoamerican Aulacorhynchus toucanets. Wilson Bull. 113: 363-372.

Navarro-Sigüenza, A. G. and Peterson, A. T. (2004) An alternative species taxonomy of the birds of Mexico. Biota Neotropica vol. 4, no. 2. Sao Paulo: Conselho Nacional de Desenvolvimento Científico e Tecnológico. Available from http://www.biotaneotropica. org.br/v4n2/pt/item?taxonomicreview (accessed March 2006).

Peterson, A. T. (2006) Taxonomy is important in conservation: A preliminary reassessment of Philippine species-level bird taxonomy. Bird Conserv. Internatn. 16: 155-173.

Peterson, A. T. and Navarro, A. G. (1999) Alternate species concepts as bases for determining priority conservation areas. Conserv. Biol. 13: 427-431.

Pitman, R. L. and Jehl, J. R. Jr. (1998) Geographic variation and reassessment of species limits in the "Masked" Boobies of the eastern Pacific Ocean. Wilson Bull. 110: 155-170.

Puebla-Olivares, F., Bonaccorso, E., Espinosa de los Monteros, A., Omland, K. E., Llorente-Bousquets, J. E., Peterson, A. T. and Navarro-Sigüenza, A. G. 2008. Speciation in the Emerald Toucanet (Aulacorhynchus prasinus) complex. Auk 125: 39-50.

Riddle, B. R. and Hafner, D. J. (1999) Species as units of analysis in ecology and biogeography, time to take the blinders off. Global Ecol. Biogeogr. 8: 433-441.

Rising, J. D. (2007). Named subspecies and their significance in contemporary ornithology. Ornithol. Monogr. 63: 4554 .
Ryder, O. A. (1986) Species conservation and systematics: the dilemma of subspecies. Trends Ecol. Evol. 1: 9-10.

SRA (Species at Risk Act) (2003) Ontario, Ottawa: Canada Gazette. Minister of Public Works and Government Services. Available from http://www.speciesatrisk.gc.ca (accessed May 2007).

Wilcove, D. S., McMillan, M. and Winston, K. C. (1993) What exactly is an endangered species? An analysis of the U.S. endangered species list: 1985-1991. Conserv. Biol. 7: 87-93.

Winker, K. (2000) A new subspecies of toucanet (Aulacorhynchus prasinus) from Veracruz, Mexico. Ornithol. Neotrop. 11: 253-257.

Winker, K., Rocque, D. A., Braile, T. M. and Pruett, C. L. (2007) Vainly beating the air: Species-concept debates need not impede progress in science or conservation. Pp. 3044 in C. Cicero and J. V. Remsen, Jr., eds. Festschrift for Ned K. Johnson: Geographic variation and evolution in birds. Ornithol. Monogr. 63.

Zink, R. M. (1994) The geography of mitochondrial DNA variation, population structure, hybridization, and species limits in the Fox Sparrow (Passerella iliaca). Evolution 48: 96-111.

Zink, R. M. (2004) The role of subspecies in obscuring avian biological diversity and misleading conservation policy. Proc. Royal Soc. London B 271: 561-564.

Zink, R. M., Blackwell-Rago, R. C. and RojasSoto, O. (1997) Species limits in the Le Conte's Thrasher (Toxostoma lecontei). Condor 99: 132-138.

Zink, R. M., Barrowclough, G. F., Atwood, J. L. and Blackwell-Rago, R. C. (200o) Genetics, taxonomy and conservation of the threatened California Gnatcatcher. Conserv. Biol. 14: 1394-1405.

Zink, R. M., Rising, J. D., Mockford, S., Horn, A. G., Wright, J. M., Leonard, M. and Westberg, M. C. (2005) Mitochondrial DNA variation, species limits, and rapid evolution of plumage coloration and size in the Savannah Sparrow. Condor 107: $21-28$. 
OCTAVIO R. ROJAS-SOTO*, ALEJANDRO ESPINOSA DE LOS MONTEROS

Departamento de Biología Evolutiva, Instituto de Ecología, A. C., km 2.5 Carretera Antigua a Coatepec No. 351, Congregación El Haya, C. P. 9107o, Xalapa, Veracruz, México.

\section{ADOLFO G. NAVARRO-SIGÜENZA}

Museo de Zoología "Alfonso L. Herrera", Facultad de Ciencias, UNAM. Apartado Postal 7o399, Ciudad Universitaria, México, D. F., México.

${ }^{*}$ Author for correspondence. E-mail: octavio.rojas@inecol.edu.mx

Received 5 April 2008; revision accepted 29 April 2009;

Published online 4 December 2009 